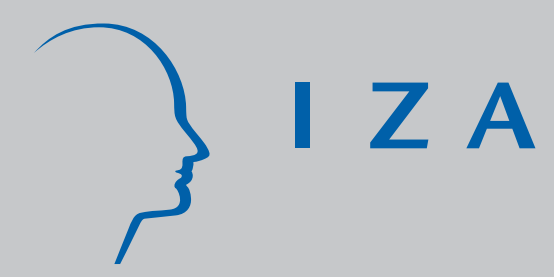

IZA DP No. 1366

The Chicken or the Egg?

Endogeneity in Labour Market

Participation of Informal Carers in England

Axel Heitmueller

October 2004 


\title{
The Chicken or the Egg? Endogeneity in Labour Market Participation of Informal Carers in England
}

\author{
Axel Heitmueller \\ Department for Work and Pensions, London, \\ London Business School and IZA Bonn
}

Discussion Paper No. 1366

October 2004

\author{
IZA \\ P.O. Box 7240 \\ 53072 Bonn \\ Germany \\ Phone: +49-228-3894-0 \\ Fax: +49-228-3894-180 \\ Email: iza@iza.org
}

\begin{abstract}
Any opinions expressed here are those of the author(s) and not those of the institute. Research disseminated by IZA may include views on policy, but the institute itself takes no institutional policy positions.

The Institute for the Study of Labor (IZA) in Bonn is a local and virtual international research center and a place of communication between science, politics and business. IZA is an independent nonprofit company supported by Deutsche Post World Net. The center is associated with the University of Bonn and offers a stimulating research environment through its research networks, research support, and visitors and doctoral programs. IZA engages in (i) original and internationally competitive research in all fields of labor economics, (ii) development of policy concepts, and (iii) dissemination of research results and concepts to the interested public.
\end{abstract}

IZA Discussion Papers often represent preliminary work and are circulated to encourage discussion. Citation of such a paper should account for its provisional character. A revised version may be available directly from the author. 


\begin{abstract}
The Chicken or the Egg? Endogeneity in Labour Market Participation of Informal Carers in England*

Informal care is a vital pillar of the British welfare state. A well-known fact in the small economic literature on informal care is the apparent negative relation between care responsibilities and labour market participation. Yet, caring and labour market participation may be endogenous. Using an instrumental variable approach and data from the British Household Panel Study for 2002 this paper shows that not accommodating for endogeneity in the labour market participation equation may significantly underestimate the impact care exhibits on the employment decision of informal carers. This is the more the case the smaller the choice of becoming a carer. Policy implications are derived.
\end{abstract}

JEL Classification: J22, I11, C10

Keywords: instrumental variable approach, informal care, endogeneity, labour market participation

Axel Heimueller

Department for Work and Pensions

Analytical Services Team

1-11 John Adam Street

London, WC2N 6HT

England

Email: Axel.Heitmueller@dwp.gsi.gov.uk

\footnotetext{
${ }^{*}$ I am grateful for comments by David Bell and Kirsty Inglis. The views expressed in this paper do not necessarily reflect the opinion of the Department for Work and Pensions.
} 


\section{Introduction}

Informal care has become an important pillar of the British welfare state. According to the 2001 Census there were about 5.2 million informal carers in England and Wales - one in ten of the population - looking after sick, disabled, and elderly people. The General Household Survey (GHS) estimates the total number to be 6.8 million carers for the whole of GB in 2000 (ONS, 2002). ${ }^{1}$ More than $14 \%$ of the working age population is currently providing unpaid care. Many of them not only care for partners and family but also for friends and neighbours.

Changes in social and economic factors are likely to further impact on the informal and formal care market in the short and medium term. Increasing longevity and rising rates of disability will undoubtedly continue to increase the demand for care services. At the same time the provision of home care by Social Services has been decreasing while higher home ownership rates among the elderly population increase the demand for these services.

Furthermore, changing family patterns such as lower marriage rates, fewer children, greater geographic mobility, and declines in intergenerational co-residence are also likely to contribute to changes in informal care patterns over time as the vast majority of informal carers looks after parents and spouses. A sound understanding of the informal care market is therefore crucial.

In the current buoyant British labour market a particular concern is the link between care and employment. Indeed many individuals combine work and caring responsibilities often at the expense of career prospects, leisure time, income, and pension entitlements (Parker 1990, Carmicheal and Charles 2003, Heitmueller and Inglis 2004). Both the Prime Minister and the Department for Trade and Industry have

\footnotetext{
${ }^{1}$ There is thus far no consensus on why there are substantial differences between the various surveys and the census but preliminary analysis suggests that they are mainly due to differences in grossing factors, different sample sizes and slight variations in the care related questions.
} 
recently emphasised the need to extend flexible working arrangements to informal carers given the apparent success of these schemes for young parents.

This paper will study how care responsibilities affect the labour market participation decision. This can occur in two main ways: adjustments at the external or internal margin. In the former, work is given up entirely or not taken up in the first place, in the latter hours of work are adjusted for example by switching from full- to part-time. In the following only adjustments at the external margin are considered. Current wisdom has it that care obligations reduce employment prospects. Yet, the central question of this paper is whether the caring decision is endogenous with respect to the labour market participation. In other words, do individuals give up work in order to engage in informal care, or do individuals take up care responsibilities in the absence of employment opportunities? Any sensible policy for informal cares will hinge on the answer to this question.

2. Labour market participation and informal care Informal care and its impact on the labour market participation has widely been ignored in the British literature. The only two recent exceptions are Carmicheal and Charles (1998, 2003) and Heitmueller and Inglis (2004). Carmicheal and Charles (1998) postulate that the effect of caring on labour supply can be broken down into a substitution and income effect. With time being scarce caring responsibilities will increase the reservation wage and reduce labour supply (substitution effect). Yet, working less will lead to a reduction in earnings (income effect). If the former outweighs the latter caring will have a negative impact on labour market participation. Employing 1985 data from the GHS Carmicheal and Charles (1998) find evidence that carers caring for more than 20 hours a week exhibit significantly lower 
participation rates compared to non-carers. However, they also show that informal carers caring for less than 20 hours are more likely to work compared to their noncaring counterparts but supply fewer hours. In subsequent analysis using 1990 data Carmicheal and Charles (2003) show that the negative effect of caring is more pronounced for women than for men among those caring for at least 10 hours a week. Heitmueller and Inglis (2004) estimate separate participation equations for carers and non-carers using panel data from the British Household Panel Study (BHPS) for waves 1-12 and find a negative gap of up to $8 \%$ in participation rates. Decomposing this gap shows that the greater part cannot be attributed to differences in observable characteristics and is likely to be due to unfavourable institutional arrangements such as a lack of flexible working hours for informal carers. The authors also show that once caring spells come to an end, employment re-entry probabilities for carers are significantly below those of their non-caring counterparts.

However, while care responsibilities undoubtedly affect employment decisions for some individuals, it is easy to construct cases where the causation might be reversed. For example, an individual might choose to provide care in order to bridge spells of unemployment or job search. Care might also be taken up by individuals who lack necessary skills in order to obtain work due to past life events such as prior caring spells, illness or parenthood. Furthermore, the existence of a formal care market enables individuals to substitute formal for informal care and individuals whose time costs exceed the costs of formal carer will do so (Pezzin and Schone, 1999, Ettner, 1995, 1996). This is likely to be the case the older an individual, the greater the degree of choice in care provision and the less favourable the general economic environment (Arber and Ginn, 1995). 
Qualitative studies have shown that many carers perceive that they have little choice in becoming a carer (Mooney et al. 2002, Lankshear et al. 2000, Lewis et al. 1999). But again, this is mainly the case for individuals providing care in their own home (co-residential care) or for long hours rather than for the large group of people caring outside their homes (extra-residential care) and for shorter hours. ${ }^{2}$

It therefore seems inappropriate to simply include care specific dummy variables as regressors. If caring is correlated with unobservables in the labour market participation equation coefficients will be biased and inconsistent. This has thus far not been addressed in the British literature. ${ }^{3}$ In the following an instrument variable approach is derived and the endogeneity of care on the employment decision is tested.

\section{The data}

The analysis in this paper is based on data from the British Household Panel Study (BHPS) in 2002. Each year over 5,000 households consisting of roughly 10,000 individuals have been interviewed. The BHPS offers a wide range of variables and is nationally representative. For the purpose of our analysis only individuals who are aged 16 to 64 (59 for women), and not working for the armed forces or in selfemployment. The sample has also been limited to England to avoid weighting issues around the new boost samples for Scotland and Wales.

Individuals are classified as carers if they answer one or both of the following questions with "yes":

\footnotetext{
${ }^{2}$ Caring for more than 10 hours a week is usually considered intensive care (DoH, 2003), however, henceforth intensive care is defined as caring for more than 20 hours a week.

${ }^{3}$ Though Heitmueller and Inglis (2004) circumvent the problem by splitting the sample into carers and non-carers and adjust for possible sample selection.
} 
Is there anyone living with you who is sick, disabled or elderly whom you look after or give special help to?

Do you provide some regular service or help for any sick, disabled or elderly person not living with you?

Two groups of carers are distinguished according to these questions, co-residential and extra-residential. The former refer to individuals caring inside, the latter to individuals caring outside their own home. Only two categories of care intensity in terms of hours cared per week can be definitively distinguished in the BHPS, individuals caring for more or less than 20 hours a week. Labour market participation is defined by whether an individual has done paid work in the week prior to the interview or has done no paid work but has had a job from which they were absent.

\section{Estimation and Choice of Instruments}

Assume labour market participation is determined by a set of observable variables $X$ which can be split into two subsets $x_{1}$ and $x_{2}$ where the former contains all exogenous and the latter all endogenous regressors. Then the impact of the regressors on the labour market decision can be estimated by

$y=\alpha+\beta_{1} x_{1}+\beta_{2} x_{2}+u$

where $y$ is an index function taking on zero if no-participation and unity if participation and $u$ is an iid error term. It is assumed that $\operatorname{Cov}\left(x_{1}, u\right)=0$ but 
$\operatorname{Cov}\left(x_{2}, u\right) \neq 0$ in which case results will be biased and inconsistent. This can be helped if an instrument variable $z$ exists so that $\operatorname{Cov}(z, u)=0$ and $\operatorname{Cov}\left(z, x_{2}\right) \neq 0$. For the above problem an instrument for care has to be identified that is highly correlated with the caring decision but not with the labour market participation. Obviously, the reason why an individual cares is because family or friends are sick or disabled and require their help. The health status of family and friends is therefore highly correlated with the caring decision (Ettner, 1996). At the same time, it is unlikely to impact on the participation decision of the individual other than through caring itself or through the individuals own health status for which can be controlled for. However, given the well-established association between disability and poverty, the health status of the household might be correlated with income which itself is likely to impact on participation. ${ }^{4}$ Hence, house ownership is included in the participation equation as a proxy for household income.

While it is possible to observe the health and disability status of co-residents in the BHPS this is not possible for extra-residential individuals. Yet, some individuals care for both co- and extra-residential individuals which helps to identify both groups. In order to maximise the variability of the instrument, a variable containing the number of sick and disabled people in the household has been chosen rather than a simple index variable. An individual is classified as sick or disabled if they report that their health limits daily activities compared to most people of the same age (Burchardt, 2003). Disability of an individual is likely to impact on the labour market participation decision. In order to avoid controlling for health status twice directly

\footnotetext{
${ }^{4}$ As to yet causation between disability and poverty has not been convincingly established.
} 
through a disability variable for individual $i$ and indirectly through the instrument, the number of disabled individuals in the household has been reduced accordingly. ${ }^{56}$ Though the number of disabled household members worked very well as an instrument for both co- and extra-residential care, a second set of instruments has been derived for extra-residential care. This allows the application of over identification tests and also ensures sufficient correlation between the overall carers variable and its instruments. The BHPS contains information on the age of the three closest friends of the respondent. Since care needs are an increasing function of age this information has been used to derive three additional instruments.

Other instruments have been constructed such as the age of the parents and the geographical proximity of parents and friends. However, the questions are not very well populated in the BHPS and decrease the sample size significantly.

\section{Results}

Tables 1 and 2 report the variable definitions and mean characteristics of the sample used. Depending on the method there are between 4915 and 4276 individuals in the sample. Around $15 \%$ of individuals are engaged in informal care of whom $28 \%$ care for people inside and $72 \%$ outside their own home. Almost $50 \%$ of all carers look after parents or parents in law and $11 \%$ provide care for spouses. Finally a substantial number of people (30\%) care for friends and neighbours. Overall labour market participation is around 77\%, yet, carers exhibit a much lower rate (67\%).

Table 4 presents the regression results of the labour market participation equation.

Model 1 and 2 are simple OLS and probit regressions including a dummy variable for

\footnotetext{
${ }^{5}$ Note that these two categories are treated as mutually exclusive when looking at co- and extraresidential care separately.

${ }^{6}$ Jenkins and Rigg (2003) define disabled individuals as those who answer "yes" to the question "Does your health limit the type of work or amount of work that you can do?” However, this variable is likely to be endogenous with regard to labour market participation rates (Burchardt 2003).
} 
care. Results are very similar and broadly in line with expectations. In particular, age, income, being non-disabled, having a degree and being married all increase the probability of employment while the presence of young children reduces it. All models also control for a set of regional dummies. ${ }^{7}$

Most interestingly, however, care responsibilities reduce participation by around 6\% and are statistically significant. The magnitude is lower compared to Carmicheal and Charles (1998) findings and also smaller than expected from the mean statistics in table 2 .

In order to test and adjust for potential endogeneity bias a Two Stage Least Squares (2SLS) method (Baum et al. 2003) and Amemiya’s Generalized Least Squares (AGLS) approach (Maddala 1983) have been employed. Column three and four in table 3 report the results. The instruments used are the number of disabled people in the household and the age of friends of the respondent as defined above. While other coefficients stay remarkably unchanged, the impact of care on labour market participation increase almost tenfold. Both Durbin-Wu-Hausman and the SmithBlundell tests indicate the presence of endogeneity in the care variable though the latter is only significant at a $10 \%$ level. Similarly, the over-identification test confirms the validity of the instruments.

Endogeneity is likely to vary with the degree of freedom in the care decision as discussed above. This is particularly the case for extra-residential carers looking after friends and neighbours though a large proportion of care provision is also directed towards parents and parents in law not living in the same household. Hence, the proposition to be tested is that endogeneity mainly occurs in extra-residential and not in co-residential care.

\footnotetext{
${ }^{7}$ Tables with all coefficients can be obtained from the author.
} 
Table 4 and 5 report results for co-residential and extra-residential care respectively for the same model specifications and the same instruments as in table 3 for the sake of comparability. ${ }^{8}$ Table 4 confirms the absence of endogeneity in the care decision for co-residential carers. Providing care within the household significantly reduces the employment probability by up to $15 \%$ other things equal. When instruments are used this again increases substantially yet none of the specification tests supports the use of instruments at common levels of significance.

In contrast, extra-residential care does not seem to impact significantly on the labour market participation decision (table 5). Although there is indication of endogeneity, none of the coefficients is significant at a 5\% level suggesting that extra-residential care has no effect on participation.

In the previous two estimations the non-carer group also contained either co- or extraresidential carers, which might have artificially decreased participation in the counterfactual category. Alternatively, one might control for co- and extra-residential care simultaneously (table 6a and 6b). Again a very strong and significant effect is found for co-residential care in the simple OLS and probit models while extraresidential care has no impact. Also, caring for co- and extra-residential care simultaneously does not affect participation. Furthermore, there is no indication of endogeneity once instruments are used. This is consistent with results in tables 4 and 5 but shed doubts on the overall findings in table 3. Note that the above results are robust even when for example only using the age of close friends as instruments and not the number of sick and disabled people in the household.

Finally, if the above hypothesis is valid one would also expect the endogeneity to be less of a problem the higher the care intensity as care becomes less of a choice and its

\footnotetext{
${ }^{8}$ A small number of individuals share households with friends in which case the age of close friends also identifies co-residential care.
} 
opportunity cost increases. Measuring care intensity in terms of hours cared for per week, an intensive carer is defined as a person caring for more than 20 hours a week and everybody else is defined as non-carer. ${ }^{9}$

Table 7 reports the results and as expected specification tests confirm that the care variable is exogenous and reduces labour market participation by up to $26 \%$ compared to non-carers.

The group of carers caring for more than 20 hours a week also contains a subgroup of individuals claiming Carers Allowance (CA). ${ }^{10}$ An individual qualifies for CA if they are caring for a severely disabled person for more than 35 hours a week and are not in 'gainful employment' or fulltime education and are aged 16 and over. ${ }^{11}$ As a consequence, their choice to take up employment is limited by the CA rules. However, even when controlling separately for this group in the models in table 6 and 7 the main results are unchanged.

Hence, there is strong evidence for a close link between endogeneity and the degree of freedom in care decisions. Results confirm findings for the U.S. (Ettner, 1995, 1996, Pezzin and Schone, 1999a, 1999b) but additionally emphasise the importance of distinguishing different care dimensions.

\section{Conclusion and implications}

Informal care is an important pillar of the British welfare system and will carry even more weight in the years to come given an aging population and reduced Social

\footnotetext{
${ }^{9}$ Clearly, hours per week is only an approximation of care intensity as individuals with high care needs may receive extra social care to cover the most intensive care needs. This would then leave the informal carer with fewer hours care although the care needs might be high.

${ }^{10}$ The BHPS is known to under represent the group of CA recipients (Heitmueller and Inglis 2004).

${ }^{11}$ For details on the CA rules see Child Poverty Action Group (2004). A person is defined to be severely disabled if they are entitled to higher or middle rates of Disability Living Allowance (DLA) care component, Attendance Allowance (AA) or Constant Attendance Allowance. Individuals are gainfully employed if they earn more than $£ 79$ per week after allowable deductions.
} 
Services. Many informal carers combine both work and caring responsibilities. Around 15\% of the English labour force was engaged in informal care in 2002. Policy makers face a trade-off. On the one hand care needs in society can only be met if people continue to provide care informally for sick, disabled or elderly friends and family. On the other hand it has been priority of the Labour government to keep people in work. As a result the double burden of care and employment often preys on the health and wellbeing of carers and reduces live chances.

It is therefore vital to understand the exact link between caring and employment decisions. Thus far the literature on informal care has postulated a causation from caring to employment. Yet, there are good arguments why this is not always the case. Evidence in this paper shows that there is a straightforward association between care and labour market participation mainly when the degree of freedom to take up care is small. However, if individuals are more likely to face a choice of becoming a carer, causation might well reverse. This is particularly the case for individuals providing few hours of care or with caring responsibilities outside their own home. In these cases conventional estimation techniques may underestimate the impact of formal care on employment.

For a government which is concerned with bringing people back in to the labour market this contains an important message. If individuals substitute care for employment due to a lack of formal care alternatives, budget constraints or inflexible working arrangements, expanding supply, making funds for formal care available and changing working patterns will enable these people to return to or remain in the labour market. Yet, if the provision of care reflects unemployability, as it seems to be the case for some groups, the policy will have to focus on the carer rather than the 
care market. For example, this may include training programmes or specifically designed job brokering.

The findings in this paper also imply that former carers are potentially a very vulnerable group. Previous evidence has shown that once caring spells come to an end re-employment prospects are significantly reduced. Instead these people might take on further caring responsibilities which might help to explains the positive correlation between past and current caring spells. 


\section{References}

Arber, S. and Ginn, J. (1995). Gender Differences in the Relationship between Paid Employment and Informal Care. Work, Employment and Society 9(3) pp. 445471.

Baum, C. F., Schaffer, M. E. and Stillman, S. (2003). Instrumental variables and GMM: Estimation and testing. Stata Journal 3(1): 1-31. Unpublished working paper version: Boston College Department of Economics Working Paper No 545. ․ http://fmwww.bc.edu/ec-p/WP545.pdf

Burchardt, T. (2003). Being and becoming: Social exclusion and the onset of disability. CASE Report 21, London School of Economics.

Carmichael, F. and Charles, S. (1998). The labour market costs of community care. Journal of Health Economics 17 (6), pp. 747-765.

Carmichael, F. and Charles, S. (2003). The opportunity costs of informal care: does gender matter? Journal of Health Economics 22 (5), pp. 781-803.

Child Poverty Action Group (2004). Welfare benefits and tax credits handbook 2004/2005. London

Department of Health (2003). Community Care Statistics 2003: Home care services, England, http://www.publications.doh.gov.uk/public/Hh12003.pdf

Ettner, S. (1995). The Impact of "Parent Care” on Female Labor Supply Decisions. Demography 32(1), pp. 63-80.

Ettner, S. (1996). The Opportunity Costs of Elder Care. Journal of Human Resources 31(1), pp. 189-205. 
Heitmueller, A. and Inglis, K. (2004). Carefree? Participation and Pay Differentials for Informal Carers in Britain. IZA Discussion Paper 1273

Jenkins, S. and Rigg, J. (2000). Disability and Disadvantage: selection, onset and duration effects. Institute for Social and Economic Research working paper no. 2003-18, Colchester, University of Essex.

Lankshear, G., Giarchi, G.G. and Cox, S. (2000). Caring Options For Entering Employment. In: Social Issues \& Social Policies Research Paper (4), Plymouth: Community Research Centre University Of Plymouth.

Lewis, S., Kagan, C., Heaton, P. and Cranshaw, M. (1999) Economic and psychological benefits from employment: the experiences and perspectives of mothers of disabled children. In: Disability \& Society 14(4), pp. 561-575.

Maddala, G. (1983). Limited-Dependent and Qualitative Variables in Econometrics. Cambridge University Press.

Mooney, A, Statham, J. and Simon, A. (2002). The Pivot Generation: Informal Care and Work after fifty. Thomas Coram Research Unit, commissioned by the Joseph Rowntree Fund. The Policy Press.

ONS (2002). Carers 2000. Office for National Statistics, London.

Parker, G. (1990). With due care and attention: a review of research on informal care. London: Family Policy Studies Centre.

Pezzin, L.E., Schone, B. (1999a). Intergenerational Household Formation, Female Labor Supply and Informal Care giving. Journal of Human Resources 34(30, pp. 475-503. 
Pezzin, L.E., Schone, B. (1999b). Parental marital Disruption and Intergenerational Transfers: An Analysis of Lone Elderly Parent and Their Children. Demography 36(3), pp. 287-297. 
Tables

Table 1: Date description

\begin{tabular}{|ll|}
\hline Variable & Description \\
\hline $\begin{array}{l}\text { Dependent Variables: } \\
\text { Independent Variables: }\end{array}$ & $(1,0)$ if participating in the labour market \\
Age & Age of individual \\
Age sq & Squared age of individual \\
Male & $(1,0)$ if individual is male \\
Disabled & $(1,0)$ if individual is disabled \\
Married & $(1,0)$ if individual is married \\
Higher degree & $(1,0)$ qualification dummy \\
Degree & $(1,0)$ qualification dummy \\
A-level & $(1,0)$ qualification dummy \\
O-level and below & $(1,0)$ qualification dummy \\
Children 0-4 & $(1,0)$ children dummy \\
Children 5-11 & $(1,0)$ children dummy \\
Children 11-15 & $(1,0)$ children dummy \\
Carer & $(1,0)$ if individual is informal carer \\
Co-care & $(1,0)$ if individual is co-residential carer \\
Extra-care & $(1,0)$ if individual is extra-residential carer \\
Intensive carer & $(1,0)$ if individual cares for $>20$ hours a week \\
Co-and extra-carer & $(1,0)$ if individual cares for co-and extra- \\
& residential individuals \\
Household size & Household size \\
House owned & $(1,0)$ if individual owns house/flat \\
\hline
\end{tabular}

Table 2: Mean statistics

\begin{tabular}{|c|c|c|c|c|c|c|}
\hline Variable & $\begin{array}{l}\text { All } \\
\text { Mean } \\
\end{array}$ & Std-div & $\begin{array}{l}\text { Non-carer } \\
\text { Mean }\end{array}$ & Std-div & $\begin{array}{l}\text { Carer } \\
\text { Mean }\end{array}$ & Std-div \\
\hline Age & 37.81 & 12.83 & 36.66 & 12.62 & 44.44 & 11.98 \\
\hline Male & 0.4680 & 0.4990 & 0.4788 & 0.4996 & 0.4055 & 0.4913 \\
\hline Disabled & 0.1174 & 0.3219 & 0.1060 & 0.3078 & 0.1834 & 0.3873 \\
\hline Married & 0.5245 & 0.4994 & 0.5029 & 0.5001 & 0.6497 & 0.4774 \\
\hline Higher degree & 0.0295 & 0.1692 & 0.0305 & 0.1721 & 0.0234 & 0.1514 \\
\hline Degree & 0.1982 & 0.3987 & 0.2057 & 0.4043 & 0.1545 & 0.3617 \\
\hline A-level & 0.2275 & 0.4192 & 0.2310 & 0.4215 & 0.2069 & 0.4054 \\
\hline O-level \& below & 0.3689 & 0.4825 & 0.3718 & 0.4834 & 0.3517 & 0.4778 \\
\hline Children 0-4 & 0.1408 & 0.3478 & 0.1508 & 0.3579 & 0.0828 & 0.2757 \\
\hline Children 5-11 & 0.2187 & 0.4134 & 0.2205 & 0.4147 & 0.2083 & 0.4064 \\
\hline Children 11-15 & 0.1613 & 0.3679 & 0.1604 & 0.3670 & 0.1669 & 0.3731 \\
\hline Household size & 3.1416 & 1.3192 & 3.1425 & 1.3132 & 3.1366 & 1.3541 \\
\hline House owned & 0.7701 & 0.4208 & 0.7659 & 0.4235 & 0.7945 & 0.4044 \\
\hline Participation & 0.7701 & 0.4208 & 0.7862 & 0.4101 & 0.6772 & 0.4679 \\
\hline Carer & 0.1475 & 0.3546 & & & & \\
\hline Co-care & 0.0413 & 0.1990 & & & 0.2800 & 0.4493 \\
\hline Extra-care & 0.1062 & 0.3081 & & & 0.7200 & 0.4493 \\
\hline Intensive carer & 0.0287 & 0.1669 & & & 0.1945 & 0.3961 \\
\hline Co-and extra carer & 0.0065 & 0.0804 & & & 0.0441 & 0.2055 \\
\hline $\mathrm{N}$ & 4915 & & 4190 & & 725 & \\
\hline
\end{tabular}


Table 3: Labour market participation, BHPS 2002

\begin{tabular}{|c|c|c|c|c|c|c|c|c|}
\hline & $\begin{array}{l}\text { OLS } \\
\text { Coefficiel }\end{array}$ & z-values & $\begin{array}{l}\text { Probit } \\
\mathrm{dF} / \mathrm{dx}\end{array}$ & z-values & $\begin{array}{l}\text { IV 2SLS } \\
\text { Coefficie }\end{array}$ & z-values & $\begin{array}{l}\text { IV Probit } \\
\mathrm{dF} / \mathrm{dx}\end{array}$ & z-values \\
\hline Constant & -0.1920 & $-2.85 * *$ & & & -0.1991 & $-2.68 * *$ & & \\
\hline Carer & -0.0576 & $-3.39 * *$ & -0.0616 & $-3.58 * *$ & -0.3452 & $-2.33 * *$ & -0.4176 & $-2.29 * *$ \\
\hline Age & 0.0484 & $14.59 * *$ & 0.0500 & $15.64 * *$ & 0.0517 & $13.99 * *$ & 0.0517 & $15.04^{* *}$ \\
\hline Age sq & -0.0007 & $-15.55^{* *}$ & -0.0007 & $-16.74 * *$ & -0.0007 & $-14.06^{* *}$ & -0.0007 & $-15.36^{* *}$ \\
\hline Male & 0.0817 & $7.79 * *$ & 0.0976 & $8.03^{* *}$ & 0.0618 & $4.68^{* *}$ & 0.0776 & $5.48 * *$ \\
\hline Disabled & -0.3131 & $-15.00 * *$ & -0.3310 & $-15.66 * *$ & -0.2985 & $-12.06^{* *}$ & -0.3074 & $-12.59 * *$ \\
\hline Married & 0.0258 & 1.95 & 0.0226 & 1.45 & 0.0185 & 1.27 & 0.0130 & 0.77 \\
\hline Higher degree & 0.1271 & $3.89 * *$ & 0.0911 & $2.72^{* *}$ & 0.0903 & $2.42 * *$ & 0.0629 & 1.67 \\
\hline Degree & 0.1209 & $6.10^{* *}$ & 0.0991 & $5.45 * *$ & 0.0917 & $3.88 * *$ & 0.0738 & $3.53^{* *}$ \\
\hline A-level & 0.0915 & $4.60 * *$ & 0.0648 & $3.63^{* *}$ & 0.0788 & $3.46 * *$ & 0.0543 & $2.75^{* *}$ \\
\hline O-level or below & 0.1053 & $5.68 * *$ & 0.0859 & $5.25 * *$ & 0.0895 & $4.14^{* *}$ & 0.0723 & $3.92 * *$ \\
\hline Children 0-4 & -0.1511 & $-8.19 * *$ & -0.1744 & $-8.19 * *$ & -0.1642 & $-7.75 * *$ & -0.1901 & $-7.73^{* *}$ \\
\hline Children 5-11 & -0.0825 & $-5.28 * *$ & -0.0874 & $-4.79 * *$ & -0.0907 & $-5.14 * *$ & -0.0950 & $-4.77 * *$ \\
\hline Children 12-15 & -0.0211 & -1.21 & -0.0236 & -1.25 & -0.0349 & -1.74 & -0.0361 & -1.72 \\
\hline Household size & -0.0159 & $-2.77 * *$ & -0.0188 & $-3.08 * *$ & -0.0078 & -1.10 & -0.0118 & -1.63 \\
\hline House owned & 0.1421 & $9.37 * *$ & 0.1548 & $9.87 * *$ & 0.1239 & $7.46^{* *}$ & 0.1354 & $7.91^{* *}$ \\
\hline Regional dummies & Yes & & Yes & & Yes & & Yes & \\
\hline$N$ & 4915 & & 4915 & & 4276 & & 4276 & \\
\hline Durbin-Wu-Hausman chi-sq & & & & & 0.02972 & & & \\
\hline Smith-Blundell chi-sq & & & & & & & 0.0527 & \\
\hline$R 2$ & 0.2216 & & 0.2059 & & & & 0.1898 & \\
\hline Hansen over-identification test & & & & & 0.31565 & & & \\
\hline
\end{tabular}


Table 4: Labour market participation, co-residential care, BHPS 2002

\begin{tabular}{|c|c|c|c|c|c|c|c|c|}
\hline & $\begin{array}{l}\text { OLS } \\
\text { Coefficier }\end{array}$ & z-values & $\begin{array}{l}\text { Probit } \\
\mathrm{dF} / \mathrm{dx}\end{array}$ & z-values & $\begin{array}{l}\text { IV 2SLS } \\
\text { Coefficient }\end{array}$ & z-values & $\begin{array}{l}\text { IV Probit } \\
\mathrm{dF} / \mathrm{dx}\end{array}$ & z-values \\
\hline Constant & -0.1898 & $-2.81 * *$ & & & -0.2033 & $-2.79 * *$ & & \\
\hline Co-carer & -0.1514 & $-4.85^{* *}$ & -0.1517 & $-4.69 * *$ & -0.3042 & -1.92 & -0.3572 & -1.78 \\
\hline Age & 0.0483 & $14.55^{* *}$ & 0.0500 & $15.62 * *$ & 0.0512 & $14.29 * *$ & 0.0514 & $15.28 * *$ \\
\hline Age sq & -0.0007 & $-15.54 * *$ & -0.0007 & $-16.75^{* *}$ & -0.0007 & $-15.05^{* *}$ & -0.0007 & $-16.22 * *$ \\
\hline Male & 0.0838 & $8.01 * *$ & 0.0999 & $8.22 * *$ & 0.0762 & $6.86^{* *}$ & 0.0906 & $7.13^{* *}$ \\
\hline Disabled & -0.3108 & $-14.90 * *$ & -0.3314 & $-15.63 * *$ & -0.2998 & $-12.42^{* *}$ & -0.3116 & $-12.96 * *$ \\
\hline Married & 0.0255 & 1.94 & 0.0222 & 1.42 & 0.0163 & 1.16 & 0.0108 & 0.65 \\
\hline Higher degree & 0.1249 & $3.87 * *$ & 0.0904 & $2.69 * *$ & 0.1015 & $2.90 * *$ & 0.0708 & $1.98 * *$ \\
\hline Degree & 0.1175 & $5.94 * *$ & 0.0974 & $5.32 * *$ & 0.0951 & $4.21 * *$ & 0.0770 & $3.78 * *$ \\
\hline A-level & 0.0867 & $4.36^{* *}$ & 0.0611 & $3.39 * *$ & 0.0718 & $3.20 * *$ & 0.0487 & $2.44 * *$ \\
\hline O-level or below & 0.1005 & $5.43 * *$ & 0.0823 & $5.00 * *$ & 0.0842 & $3.92 * *$ & 0.0681 & $3.63^{* *}$ \\
\hline Children 0-4 & -0.1505 & $-8.18 * *$ & -0.1733 & $-8.14^{* *}$ & -0.1516 & $-7.65 * *$ & -0.1742 & $-7.67 * *$ \\
\hline Children 5-11 & -0.0820 & $-5.25 * *$ & -0.0866 & $-4.74 * *$ & -0.0873 & $-5.10 * *$ & -0.0911 & $-4.70^{* *}$ \\
\hline Children 12-15 & -0.0222 & -1.27 & -0.0244 & -1.28 & -0.0304 & -1.59 & -0.0311 & -1.54 \\
\hline Household size & -0.0139 & $-2.41 * *$ & -0.0171 & $-2.78 * *$ & -0.0078 & -1.07 & -0.0120 & -1.63 \\
\hline House owned & 0.1390 & $9.18^{* *}$ & 0.1516 & $9.66^{* *}$ & 0.1167 & $7.03 * *$ & 0.1276 & $7.45^{* *}$ \\
\hline Regional dummies & Yes & & Yes & & Yes & & Yes & \\
\hline$N$ & 4915 & & 4915 & & 4276 & & 4276 & \\
\hline Durbin-Wu-Hausman chi-sq & & & & & 0.2472 & & & \\
\hline Smith-Blundell chi-sq & & & & & & & 0.2993 & \\
\hline$R 2$ & 0.2244 & & 0.2076 & & & & 0.1893 & \\
\hline Hansen over-identification test & & & & & 0.1031 & & & \\
\hline
\end{tabular}

Note: $* *$ indicates $95 \%$ significance level, robust z-values. 
Table 5: Labour market participation, extra-residential care, BHPS 2002

\begin{tabular}{|c|c|c|c|c|c|c|c|c|}
\hline & $\begin{array}{l}\text { OLS } \\
\text { Coefficier }\end{array}$ & z-values & $\begin{array}{l}\text { Probit } \\
\mathrm{dF} / \mathrm{dx}\end{array}$ & z-values & $\begin{array}{l}\text { IV 2SLS } \\
\text { Coefficient }\end{array}$ & z-values & $\begin{array}{l}\text { IV Probit } \\
\mathrm{dF} / \mathrm{dx}\end{array}$ & z-values \\
\hline Constant & -0.1935 & $-2.87 * *$ & & & -0.1872 & $-2.14^{* *}$ & & \\
\hline Extra-carer & -0.0113 & -0.59 & -0.0176 & -0.92 & -1.0416 & -1.68 & -0.9142 & -1.81 \\
\hline Age & 0.0484 & $14.57 * *$ & 0.0499 & $15.60 * *$ & 0.0524 & $11.72 * *$ & 0.0526 & $11.90 * *$ \\
\hline Age sq & -0.0007 & $-15.64 * *$ & -0.0007 & $-16.79 * *$ & -0.0007 & $-10.48 * *$ & -0.0007 & $-10.77 * *$ \\
\hline Male & 0.0838 & $7.97 * *$ & 0.0996 & $8.19 * *$ & 0.0334 & 1.14 & 0.0456 & 1.51 \\
\hline Disabled & -0.3155 & $-15.14 * *$ & -0.3342 & $-15.79 * *$ & -0.3100 & $-10.45^{* *}$ & -0.3227 & $-10.20 * *$ \\
\hline Married & 0.0258 & 1.94 & 0.0225 & 1.44 & 0.0244 & 1.28 & 0.0191 & 0.89 \\
\hline Higher degree & 0.1296 & $3.95 * *$ & 0.0925 & $2.78 * *$ & 0.0833 & 1.66 & 0.0546 & 1.12 \\
\hline Degree & 0.1227 & $6.19 * *$ & 0.1008 & $5.55 * *$ & 0.0991 & $3.35 * *$ & 0.0792 & $3.07 * *$ \\
\hline A-level & 0.0919 & $4.61 * *$ & 0.0655 & $3.66^{* *}$ & 0.1053 & $3.25 * *$ & 0.0792 & $2.80 * *$ \\
\hline O-level or below & 0.1060 & $5.71 * *$ & 0.0867 & $5.29 * *$ & 0.1158 & $3.94 * *$ & 0.0980 & $3.73^{* *}$ \\
\hline Children 0-4 & -0.1486 & $-8.05^{* *}$ & -0.1711 & $-8.06 * *$ & -0.1851 & $-5.85 * *$ & -0.2238 & $-5.54 * *$ \\
\hline Children 5-11 & -0.0818 & $-5.23 * *$ & -0.0867 & $-4.75 * *$ & -0.0949 & $-4.31 * *$ & -0.1015 & $-3.92 * *$ \\
\hline Children 12-15 & -0.0199 & -1.14 & -0.0220 & -1.16 & -0.0389 & -1.58 & -0.0420 & -1.53 \\
\hline Household size & -0.0171 & $-2.97 * *$ & -0.0202 & $-3.31 * *$ & -0.0175 & $-2.18 * *$ & -0.0215 & $-2.50 * *$ \\
\hline House owned & 0.1427 & $9.39 * *$ & 0.1552 & $9.89 * *$ & 0.1482 & $6.03 * *$ & 0.1679 & $6.00 * *$ \\
\hline Regional dummies & Yes & & Yes & & Yes & & Yes & \\
\hline$N$ & 4915 & & 4915 & & 4276 & & 4276 & \\
\hline Durbin-Wu-Hausman chi-sq & & & & & 0.02342 & & & \\
\hline Smith-Blundell chi-sq & & & & & & & 0.0223 & \\
\hline$R 2$ & 0.2195 & & 0.2036 & & & & 0.1897 & \\
\hline Hansen over-identification test & & & & & 0.41609 & & & \\
\hline
\end{tabular}

Note: $* *$ indicates $95 \%$ significance level, robust z-values. 
Table 6a: Labour market participation, extra-residential and co-residential care, BHPS 2002

\begin{tabular}{|c|c|c|c|c|c|c|c|c|}
\hline \multirow[b]{2}{*}{ Constant } & \multicolumn{2}{|c|}{$\begin{array}{l}\text { OLS } \\
\text { Coefficient z-values }\end{array}$} & \multirow[t]{2}{*}{$\begin{array}{l}\text { Probit } \\
\mathrm{dF} / \mathrm{dx}\end{array}$} & \multirow[t]{2}{*}{ z-values } & \multicolumn{2}{|c|}{$\begin{array}{l}\text { IV 2SLS } \\
\text { Coefficient z-values }\end{array}$} & \multirow[t]{2}{*}{$\begin{array}{l}\text { IV Probit } \\
\mathrm{dF} / \mathrm{dx}\end{array}$} & \multirow[t]{2}{*}{ z-values } \\
\hline & -0.1897 & $-2.81 * *$ & & & -0.1907 & $-2.26 * *$ & & \\
\hline Co-carer & -0.1544 & $-4.93 * *$ & -0.1569 & $-4.80 * *$ & -0.2629 & -1.38 & -0.2897 & -1.17 \\
\hline Extra-carer & -0.0205 & -1.08 & -0.0275 & -1.41 & -0.9282 & -1.57 & -0.9066 & -1.72 \\
\hline Age & 0.0483 & $14.55^{* *}$ & 0.0500 & $15.64 * *$ & 0.0524 & $12.17^{* *}$ & 0.0528 & $12.46^{* *}$ \\
\hline Age sq & -0.0007 & $-15.52 * *$ & -0.0007 & $-16.73^{* *}$ & -0.0007 & $-10.94 * *$ & -0.0007 & $-11.27^{* *}$ \\
\hline Male & 0.0829 & $7.91^{* *}$ & 0.0988 & $8.12 * *$ & 0.0378 & 1.36 & 0.0486 & 1.67 \\
\hline Disabled & -0.3104 & $-14.88^{* *}$ & -0.3303 & $-15.59 * *$ & -0.3014 & $-10.42^{* *}$ & -0.3145 & $-10.13^{* *}$ \\
\hline Married & 0.0256 & 1.94 & 0.0223 & 1.43 & 0.0227 & 1.26 & 0.0177 & 0.86 \\
\hline Higher degree & 0.1245 & $3.86^{* *}$ & 0.0901 & $2.68 * *$ & 0.0769 & 1.61 & 0.0502 & 1.05 \\
\hline Degree & 0.1174 & $5.94 * *$ & 0.0973 & $5.32 * *$ & 0.0910 & $3.18 * *$ & 0.0734 & $2.88 * *$ \\
\hline A-level & 0.0872 & $4.39 * *$ & 0.0618 & $3.43 * *$ & 0.0951 & $3.03 * *$ & 0.0720 & $2.55^{* *}$ \\
\hline O-level or below & 0.1010 & $5.45 * *$ & 0.0829 & $5.04 * *$ & 0.1040 & $3.56^{* *}$ & 0.0892 & $3.36^{* *}$ \\
\hline Children 0-4 & -0.1512 & $-8.22 * *$ & -0.1746 & $-8.19 * *$ & -0.1839 & $-6.08 * *$ & -0.2233 & $-5.77 * *$ \\
\hline Children 5-11 & -0.0822 & $-5.26 * *$ & -0.0871 & $-4.76^{* *}$ & -0.0955 & $-4.54 * *$ & -0.1024 & $-4.12 * *$ \\
\hline Children 12-15 & -0.0224 & -1.28 & -0.0248 & -1.30 & -0.0406 & -1.72 & -0.0443 & -1.68 \\
\hline Household size & -0.0139 & $-2.40 * *$ & -0.0170 & $-2.76^{* *}$ & -0.0113 & -1.26 & -0.0157 & -1.67 \\
\hline House owned & 0.1393 & $9.20 * *$ & 0.1522 & $9.69 * *$ & 0.1395 & $5.79 * *$ & 0.1592 & $5.76 * *$ \\
\hline Regional dummies & Yes & & Yes & & Yes & & Yes & \\
\hline$N$ & 4915 & & 4915 & & 4276 & & 4276 & \\
\hline Durbin-Wu-Hausman chi-sq & & & & & 0.07451 & & & \\
\hline Smith-Blundell chi-sq & & & & & & & 0.0731 & \\
\hline$R 2$ & 0.2246 & & 0.208 & & & & 0.1902 & \\
\hline Hansen over-identification test & & & & & 0.50992 & & & \\
\hline
\end{tabular}

Note: **indicates $95 \%$ significance level, robust z-values. 
Table 6b: Labour market participation, extra-residential and co-residential care and overlaps, BHPS 2002

\begin{tabular}{|c|c|c|c|c|c|c|c|c|}
\hline & $\begin{array}{l}\text { OLS } \\
\text { Coefficien }\end{array}$ & z-values & $\begin{array}{l}\text { Probit } \\
\mathrm{dF} / \mathrm{dx}\end{array}$ & z-values & $\begin{array}{l}\text { IV 2SLS } \\
\text { Coefficien }\end{array}$ & z-values & $\begin{array}{l}\text { IV Probit } \\
\mathrm{dF} / \mathrm{dx}\end{array}$ & z-values \\
\hline Constant & -0.1869 & $-2.77 * *$ & & & -0.0737 & -0.34 & & \\
\hline Co-and extra carer & -0.1545 & -1.81 & -0.1424 & -1.81 & -7.3767 & -0.80 & -0.8640 & -0.85 \\
\hline Co-carer & -0.1551 & $-4.95 * *$ & -0.1574 & $-4.82 * *$ & 0.5285 & 0.50 & 0.2069 & 0.64 \\
\hline Extra-carer & -0.0111 & -0.57 & -0.0181 & -0.90 & -0.4520 & -0.43 & -0.5906 & -0.37 \\
\hline Age & 0.0482 & $14.46^{* *}$ & 0.0499 & $15.59 * *$ & 0.0450 & $3.56^{* *}$ & 0.0435 & $3.37 * *$ \\
\hline Age sq & -0.0007 & $-15.42 * *$ & -0.0007 & $-16.68 * *$ & -0.0006 & $-4.15^{* *}$ & -0.0006 & $-4.03 * *$ \\
\hline Male & 0.0833 & $7.94^{* *}$ & 0.0992 & $8.14^{* *}$ & 0.0484 & 1.15 & 0.0617 & 1.25 \\
\hline Disabled & -0.3099 & $-14.84 * *$ & -0.3303 & $-15.58 * *$ & -0.3486 & $-5.12 * *$ & -0.4019 & $-3.76 * *$ \\
\hline Married & 0.0262 & $1.99 * *$ & 0.0230 & 1.48 & 0.0511 & 1.15 & 0.0534 & 1.01 \\
\hline Higher degree & 0.1250 & $3.86^{* *}$ & 0.0905 & $2.69 * *$ & 0.1386 & 1.18 & 0.1037 & 1.08 \\
\hline Degree & 0.1174 & $5.93 * *$ & 0.0974 & $5.32 * *$ & 0.1114 & $2.23 * *$ & 0.0939 & 1.95 \\
\hline A-level & 0.0868 & $4.37 * *$ & 0.0615 & $3.42 * *$ & 0.0862 & 1.87 & 0.0623 & 1.29 \\
\hline O-level or below & 0.1012 & $5.47 * *$ & 0.0833 & $5.05^{* *}$ & 0.1392 & $2.06 * *$ & 0.1287 & $1.99 * *$ \\
\hline Children 0-4 & -0.1512 & $-8.22 * *$ & -0.1747 & $-8.19 * *$ & -0.1618 & $-2.79 * *$ & -0.1855 & $-2.56 * *$ \\
\hline Children 5-11 & -0.0815 & $-5.22 * *$ & -0.0863 & $-4.72 * *$ & -0.0746 & -1.57 & -0.0720 & -1.41 \\
\hline Children 12-15 & -0.0219 & -1.26 & -0.0242 & -1.27 & -0.0406 & -1.10 & -0.0443 & -1.04 \\
\hline Household size & -0.0136 & $-2.36 * *$ & -0.0167 & $-2.71 * *$ & -0.0135 & -0.84 & -0.0185 & -1.18 \\
\hline House owned & 0.1378 & $9.11 * *$ & 0.1505 & $9.58 * *$ & 0.1132 & $2.70 * *$ & 0.1185 & 1.93 \\
\hline Regional dummies & Yes & & Yes & & Yes & & Yes & \\
\hline$N$ & 4915 & & 4915 & & 4276 & & 4276 & \\
\hline Durbin-Wu-Hausman chi-sq & & & & & 0.0677 & & & \\
\hline Smith-Blundell chi-sq & & & & & & & 0.0751 & \\
\hline$R 2$ & 0.2254 & & 0.2086 & & & & 0.1909 & \\
\hline Hansen over-identification test & & & & & 0.7035 & & & \\
\hline
\end{tabular}

Note: **indicates 95\% significance level, robust z-values. 
Table 7: Labour market participation, intensive carer, BHPS 2002

\begin{tabular}{|c|c|c|c|c|c|c|c|c|}
\hline & $\begin{array}{l}\text { OLS } \\
\text { Coefficier }\end{array}$ & z-values & $\begin{array}{l}\text { Probit } \\
\mathrm{dF} / \mathrm{dx}\end{array}$ & z-values & $\begin{array}{l}\text { IV 2SLS } \\
\text { Coefficient }\end{array}$ & z-values & $\begin{array}{l}\text { IV Probit } \\
\mathrm{dF} / \mathrm{dx}\end{array}$ & z-values \\
\hline Constant & -0.1849 & $-2.75^{* *}$ & & & -0.1880 & $-2.58 * *$ & & \\
\hline Intensive carer & -0.2566 & $-6.76^{* *}$ & -0.2731 & $-6.58 * *$ & -0.4662 & $-1.96 * *$ & -0.5597 & -1.83 \\
\hline Age & 0.0485 & $14.66^{* *}$ & 0.0504 & $15.73^{* *}$ & 0.0515 & $14.41^{* *}$ & 0.0518 & $15.35^{* *}$ \\
\hline Age sq & -0.0007 & $-15.63 * *$ & -0.0007 & $-16.85^{* *}$ & -0.0007 & $-15.22^{* *}$ & -0.0007 & $-16.35^{* *}$ \\
\hline Male & 0.0810 & $7.76^{* *}$ & 0.0973 & $7.99 * *$ & 0.0705 & $6.10 * *$ & 0.0852 & $6.54 * *$ \\
\hline Disabled & -0.3099 & $-14.87 * *$ & -0.3321 & $-15.65 * *$ & -0.3006 & $-12.47 * *$ & -0.3139 & $-13.11 * *$ \\
\hline Married & 0.0267 & $2.03 * *$ & 0.0235 & 1.50 & 0.0180 & 1.28 & 0.0123 & 0.74 \\
\hline Higher degree & 0.1226 & $3.81 * *$ & 0.0890 & $2.63 * *$ & 0.0966 & $2.74 * *$ & 0.0677 & 1.86 \\
\hline Degree & 0.1135 & $5.76^{* *}$ & 0.0942 & $5.11 * *$ & 0.0882 & $3.75 * *$ & 0.0712 & $3.33^{* *}$ \\
\hline A-level & 0.0832 & $4.21 * *$ & 0.0585 & $3.23^{* *}$ & 0.0641 & $2.75^{* *}$ & 0.0422 & $2.00 * *$ \\
\hline O-level or below & 0.0973 & $5.28 * *$ & 0.0795 & $4.80 * *$ & 0.0782 & $3.49 * *$ & 0.0626 & $3.17 * *$ \\
\hline Children 0-4 & -0.1486 & $-8.09 * *$ & -0.1722 & $-8.09 * *$ & -0.1470 & $-7.43^{* *}$ & -0.1697 & $-7.50 * *$ \\
\hline Children 5-11 & -0.0801 & $-5.13^{* *}$ & -0.0850 & $-4.64 * *$ & -0.0843 & $-4.91 * *$ & -0.0881 & $-4.56 * *$ \\
\hline Children 12-15 & -0.0237 & -1.37 & -0.0257 & -1.35 & -0.0328 & -1.70 & -0.0336 & -1.65 \\
\hline Household size & -0.0145 & $-2.52 * *$ & -0.0176 & $-2.87 * *$ & -0.0097 & -1.42 & -0.0137 & $-1.96 * *$ \\
\hline House owned & 0.1362 & $9.03 * *$ & 0.1491 & $9.49 * *$ & 0.1148 & $6.86^{* *}$ & 0.1259 & $7.25 * *$ \\
\hline Regional dummies & Yes & & Yes & & Yes & & Yes & \\
\hline$N$ & 4915 & & 4915 & & 4276 & & 4276 & \\
\hline Durbin-Wu-Hausman chi-sq & & & & & 0.2962 & & & \\
\hline Smith-Blundell chi-sq & & & & & & & 0.336 & \\
\hline$R 2$ & 0.2294 & & 0.2118 & & & & 0.1894 & \\
\hline Hansen over-identification test & & & & & 0.11715 & & & \\
\hline
\end{tabular}

Note: **indicates $95 \%$ significance level, robust z-values. 